\title{
FAKTOR-FAKTOR YANG MEMPENGARUHI PERILAKU KEPATUHAN WAJIB PAJAK BADAN DI KOTA SEMARANG
}

\author{
Wawan Setiawan ${ }^{1}$ \\ Nirsetyo Wahdi ${ }^{2}$ \\ Willyanto Kartiko Kusumo ${ }^{3}$
}

\author{
Fakultas Ekonomi, Universitas Semarang \\ uaone@usm.ac.id ${ }^{1}$; nirsetyo@usm.ac.id ; willyanto@usm.ac.id ${ }^{3}$
}

Diterima: Agustus 2019, Disetujui: September 2019, Dipublikasikan: Oktober 2019

\begin{abstract}
The purpose of this research is toprovideempiricalevidence about many factors which influence the corporate taxpayers' compliance behaviorin Semarang. The population and sample in this research is Corporate Taxpayers are registered in Semarang. Corporate Taxpayercanbe formas a Limited Liability Company"Perseroan Terbatas"(PT), commanditaire vennootschap (CV), foundation, orthe other organization which the taxationis represented by some staff accountantsand taxes. Hypothesis in this research was tested using logistic regression analysis because the dependent variable in this studyis a dummy variable. The result of this research are: General Fairness has not a significant impact on corporate tax compliance, Reciprocal Government has a positive and significant impact on corporate tax payer compliance, Tax Rate Structurehas a positive and significant on corporate tax payer compliance, specific provisions has a positive and significant impact on corporate tax payer compliance.
\end{abstract}

Keywords: General Fairness, Reciprocal Government, Taxpayer Compliance

\begin{abstract}
Abstrak
Tujuan dalam penelitian ini adalah untuk memberikan bukti empiris tentang Faktor-Faktor Yang Mempengaruhi Perilaku Kepatuhan Wajib Pajak Badan Di Kota Semarang. Populasi dan Sampel dalam penelitian ini adalah Wajib Pajak Badan yang terdaftar di kota Semarang. Wajib Pajak Badan dapat berupa Perseroan Terbatas (PT), Perusahaan Komanditer (CV), yayasan, ataupun organisasi lainnya yang pengelolaan perpajakannya diwakili oleh beberapa orang staf akuntansi dan perpajakan. Untuk menguji hipotesis dalam penelitian ini menggunakan analisis regresi logistik (Logistic Regression) karena variabel dependen dalam penelitian ini merupakan variabel dummy. Hasil yang diperoleh dalam penelitian ini adalah : Keadilan Umum / General Fairness tidak berpengaruh signifikan terhadap Kepatuhan Wajib Pajak Badan, Timbal Balik Pemerintah berpengaruh signifikan dan positif terhadap Kepatuhan Wajib Pajak Badan, Struktur Tarif Pajak berpengaruh signifikan dan positif terhadap Kepatuhan Wajib Pajak Badan, Ketentuan-ketentuan Khusus berpengaruh signifikan dan positif terhadap Kepatuhan Wajib Pajak Badan.

Kata Kunci : Keadilan secara umum, Timbal Balik Pemerintah, Kepatuhan Wajib Pajak.
\end{abstract}




\section{Pendahuluan}

Pajak masih menjadi primadona penerimaan utama negara Indonesia yang akan digunakan untuk membiayai pengeluaran pemerintah dan pembangunan. Semakin besarnya pengeluaran pemerintah dalam rangka pembiayaan negara menuntut peningkatan penerimaan negara yang salah satunya berasal dari penerimaan pajak. Direktorat Jenderal (Ditjen) Pajak sebagai instansi pemerintahan di bawah Departemen Keuangan sebagai pengelola sistem perpajakan di Indonesia berusaha meningkatkan penerimaan pajak dengan mereformasi pelaksanaan sistem perpajakan yang lebih modern.

Langkah pemerintah untuk meningkatkan penerimaan dari sektor perpajakan dimulai dengan melakukan reformasi perpajakan secara menyeluruh pada tahun 1983, dan sejak saat itulah, Indonesia menganut sistem self assesment. Penerapan self assesment system akan efektif apabila kondisi kepatuhan sukarela (voluntary compliance) pada masyarakat telah terbentuk (Darmayanti, 2004). Kenyataan yang ada di Indonesia menunjukkan tingkat kepatuhan masih rendah, hal ini bisa dilihat dari belum optimalnya penerimaan pajak yang tercermin dari tax gap dan tax ratio (Mustikasari, 2007).

Pengesahan Undang-Undang Nomor 36 Tahun 2008 tentunya akan menimbulkan reaksi yang beragam dari masyarakat, terutama yang terdaftar sebagai Wajib Pajak, baik Wajib Pajak Orang Pribadi (WP OP) maupun Wajib Pajak Badan (WP Badan). Salah satu bentuk reaksi masyarakat dapat dilihat dari perilaku kepatuhan pajak. Perilaku kepatuhan pajak menjadi sesuatu yang sangat penting karena pada saat yang bersamaan akan timbul upaya penghindaran pajak (tax evasion) yang berdampak pada besarnya penerimaan negara dari pajak.

Untuk dapat menjadikan pajak sebagai pendapatan Negara yang potensial untuk membiayai pembangunan Negara, Direktoral Jenderal Pajak berupaya mengintensifikasi dan ekstensifikasi penggalian potensi pajak, maka dioptimalkan untuk mengintegrasikan dan meningkatkan kegiatan penyuluhan, pelayanan dan penegakan hukum secara selektif, dan peningkatan administrasi perpajakan. Namun untuk menjadikan pajak sebagai pendapatan Negara yang yang sangat berperan banyak kendala yang harus dihadapi, baik berasal dari kalangan masyarakat selaku Wajib Pajak maupun pihak 
otoritas pajak sendiri selaku fiskus serta peraturan Undang-undang pajak yang berlaku (Wardhani, 2005).

Kendala pemungutan pajal yang berasal dari masyarakat disebut perlawanan pasif, hal ini disebabkan oleh perkembangan intelektual dan moral masyarakat yang semakin lama semakin pandai menghindari untuk membayar pajak. Selain itu, sistem perpajakan yang sulit dipahami oleh masyarakat dan birokrasi yang tidak praktis jika masyarakat ingin membayar pajak yang menyebabkan keengganan dalam membayar pajak. Sedangkan kendala yang berasal dari fiskus disebut juga perlawanan aktif yang meliputi semua usaha dan perbuatan yang secara langsung oleh fiskus dengan tujuan untuk menghindari pajak, antara lain adalah usaha untuk meringankan beban pajak dengan tidak melanggar undang-undang (tax avoidance), misalnya dengan mengecilkan jumlah pembayaran dari jumlah yang seharusnya. Yang kedua adalah usaha meringankan beban pajak dengan cara melanggar undang-undang misalnya melakukan penggelapan pajak (Wardhani, 2005).

Berdasarkan data yang disampaikan oleh Kepala Kantor Wilayah Pajak Kanwil DJP Jateng I, bahwa kepatuhan Wajib Pajak turun 10\% dari tahun sebelumnya yang mencapai 70\%. Selama bulan Januari hingga Oktober 2012, tingkat kepatuhan wajib pajak rata-rata hanya $60 \%$. Selama tiga bulan terakhir, Kanwil DJP jateng telah menerima pajak baru sebanyak Rp.7.2 trilin atau 65\% dari target penerimaan tahun ini. Dari pihak kantor pajak telah melakukan sejumlah langkah dengan cara konseling sampai memanggil wajib pajak untuk memperbaiki setoran. Hal ini dalam upaya untuk mengejar kekurangan 35\% tersebut. Selain itu berdasarkan data Indeks Kepatuhan Pajak Internasional diketahui bahwa Indonesia menempati rangking ke 24 dari 31 Negara. Hal ini menunjukan bahwa secara internasional tingkat kepatuhan wajib pajak di Indonesia masih rendah. Sedangkan Negara tetanggai Indonesia yaitu Malaysia telah menduduki rangking ke 8 dan rangking 1 di duduki oleh Singapura.

Mengenai uji kepatuhan telah diteliti oleh Jackson dan Milliron (dalam Richardson, 2006), salah satu variabel nonekonomi kunci dari perilaku kepatuhan pajak adalah dimensi keadilan pajak. Menurur Vogel, Spicer, dan Becker (dalam Richardson, 2006) pembayar pajak cenderung untuk menghindari membayar pajak jika mereka menganggap sistem pajak tidak adil. Hal tersebut menunjukkan pentingnya dimensi 
keadilan pajak sebagai variabel yang mempengaruhi perilaku kepatuhan pembayar pajak.

Penelitian-peneltian sebelumnya mengenai pengaruh dimensi keadilan pajak terhadap perilaku kepatuhan menunjukkan ketidakkonsistenan hasil penelitian. Jackson dan Milliron (1986) dan Richardson dan Sawyer (2001), seperti yang dikutip Richardson (2006), menyatakan bahwa alasan utama ketidakkonsistenan ini adalah sifat multidimensi dari keadilan pajak sebagai variabel kepatuhan pajak. Christensen dkk. (dalam Azmi dan Perumal, 2008) menyatakan bahwa keadilan sulit didefinisikan karena empat masalah utama: (1) merupakan masalah dimensional, (2) dapat didefinisikan pada tingkat individu maupun pada mayarakat luas, (3) keadilan terkait dengan kompleksitas, dan (4) kurangnya keadilan dapat menjadikan pertimbangan atau menyebabkan ketidakpatuhan. Penelitian-penelitian mengenai dampak dimensi keadilan terhadap tingkat kepatuhan pajak pada umumnya banyak dilakukan di negara-negara barat, seperti Amerika Serikat dan Australia namun hanya sedikit yang dilakukan di negaranegara Asia, seperti Hong Kong dan Malaysia. Penelitian tersebut dikaji dalam usaha untuk mencapai target pajak, dimana perlu ditumbuhkan kesadaran dan kepatuhan masyarakat Wajib Pajak untuk memenuhi kewajiban pajak sesuai dengan ketentuan yang berlaku. Mengingat kesadaran dan kepatuhan wajib pajak merupakan faktor penting bagi peningkatan penerimaan pajak, maka perlu secara intensif dikaji tentang faktor-faktor yang mempengaruhi kepatuhan wajib pajak, khususnya Wajib Pajak badan (Mustikasari, 2007).

\section{Rumusan Masalah}

Berdasarkan latar belakang dan beberapa alasan tersebut, pokok permasalahan dari penelitian ini adalah:

1. Apakah tingkat keadilan secara umum (general fairness) sebagai salah satu dimensi keadilan pajak berpengaruh terhadap perilaku kepatuhan WP Badan di kota Semarang ?

2. Apakah timbal balik yang diterima pemerintah (exchanges with government) sebagai salah satu dimensi keadilan pajak berpengaruh terhadap perilaku kepatuhan WP Badan di kota Semarang?

3. Apakah ketentuan-ketentuan yang diberlakukan secara khusus (special provisions) 
sebagai salah satu dimensi keadilan pajak berpengaruh terhadap perilaku kepatuhan WP Badan di kota Semarang?

4. Apakah struktur tarif pajak (tax rate structures) sebagai salah satu dimensi keadilan pajak berpengaruh terhadap perilaku kepatuhan WP Badan di kota Semarang?

\section{Tujuan Penelitian}

Berdasarkan latar belakang dan rumusan masalah di atas, tujuan yang ingin dicapai dalam penelitian ini adalah :

1. Untuk mengetahui pengaruh tingkat keadilan secara umum (general fairness) sebagai salah satu dimensi keadilan pajak terhadap perilaku kepatuhan WP Badan di kota Semarang.

2. Untuk mengetahui pengaruh timbal balik yang diterima pemerintah (exchanges with government) sebagai salah satu dimensi keadilan pajak terhadap perilaku kepatuhan WP Badan di kota Semarang.

3. Untuk mengetahui pengaruh kepentingan pribadi (self interest) sebagai salah satu dimensi keadilan pajak terhadap perilaku kepatuhan WP Badan di kota Semarang.

4. Untuk mengetahui pengaruh ketentuan-ketentuan yang diberlakukan secara khusus (special provisions) sebagai salah satu dimensi keadilan pajak terhadap perilaku kepatuhan WP Badan di kota Semarang.

5. Untuk mengetahui pengaruh struktur tarif pajak (tax rate structures) sebagai salah satu dimensi keadilan pajak terhadap perilaku kepatuhan WP Badan di kota Semarang.

\section{Manfaat Penelitian}

Hasil penelitian ini diharapkan dapat memberikan manfaat sebagai berikut:

1. Sebagai tambahan literatur penelitian mengenai pengaruh dimensi pengendalian pajak terhadap perilaku kepatuhan pajak.

2. Sebagai informasi bagi masyarakat dalam upaya peningkatan kualitas sistem perpajakan, khususnya di kota Semarang.

3. Sebagai informasi yang bermanfaat dan menambah wawasan. 


\section{Tinjauan Pustaka Dan Pengembangan Hipotesis}

\section{Keadilan Pajak}

Adil menurut Kamus Besar Bahasa Indonesia adalah (1) sama berat, tidak berat sebelah, tidak memihak; (2) berpihak kepada yang benar, berpegang pada kebenaran; dan (3) sepatutnya, tidak sewenang-wenang. Sedangkan keadilan adalah sifat (perbuatan atau perlakuan) yg adil. Jadi dapat disimpulkan bahwa keadilan pajak adalah sifat (perbuatan atau perlakuan) yang tidak sewenang-wenang atau tidak berat sebelah atas sistem perpajakan yang berlaku. Persepsi masyarakat mengenai keadilan sistem perpajakan yang berlaku di suatu sangat mempengaruhi pelaksanaan perpajakan yang baik di negara tersebut. Persepsi masyarakat ini akan mempengaruhi perilaku kepatuhan pajak dan perilaku penghindaran pajak (tax evasion). Masyarakat akan cenderung tidak patuh dan menghindari kewajiban pajak jika merasa sistem pajak yang berlaku tidak adil.

Penelitian yang menghubungkan dimensi keadilan pajak dan tingkat kepatuhan pajak oleh Jackson dan Milliron (1986) serta Richardson dan Sawyer (2001), dalam Richardson (2006), menunjukkan pentingnya pajak melekat pada keadilan sebagai sebuah variabel yang dapat mempengaruhi perilaku kepatuhan pajak di masyarakat. Dimensi keadilan pajak bahkan diidentifikasi sebagai variabel nonekonomi kunci yang mempengaruhi tingkat kepatuhan pajak. Namun,

Richardson (2006) menemukan bahwa hasil dari penelitian-penelitian mengenai pengaruh dimensi keadilan pajak terhadap tingkat kepatuhan pajak ini tidak konsisten. Salah satu alasan utama ketidakkonsistenan hasil ini adalah sifat multidimensional dari keadilan pajak sebagai variabel kepatuhan pajak yang juga dipengaruhi budaya nasional Hofstede. Christensen dkk. (dalam Azmi dan Perumal, 2008) menyatakan bahwa persepsi keadilan sulit didefinisikan karena empat masalah utama: (1) merupakan masalah dimensional, (2) dapat didefinisikan pada tingkat individu maupun pada mayarakat luas, (3) keadilan terkait dengan kompleksitas, dan (4) kurangnya keadilan dapat menjadikan pertimbangan atau menyebabkan ketidakpatuhan.

Richardson (2006) melakukan penelitian mengenai dimensi keadilan pajak sebagai variabel kepatuhan pajak di Hongkong. Richardson (2006) meneliti apakah dimensi-dimensi yang dikembangkan oleh Gerbing (1988) akan mempengaruhi tingkat kepatuhan di Hong Kong yang memiliki budaya yang berbeda dengan Amerika Serikat. 
Richardson (2006) dalam penelitiannya juga menambahkan satu dimensi baru yaitu, middle income earners tax share/burden. Penambahan dimensi keadilan ini disesuaikan dengan budaya dan sistem perpajakan yang berlaku di Hong Kong.

\section{Tingkat Kepatuhan Pajak}

Pajak menurut Pasal 1 UU No. 28 Tahun 2007 tentang Ketentuan Umum dan Tata Cara Perpajakan adalah kontribusi wajib kepada negara yang terutang oleh orang pribadi atau badan yang bersifat memaksa berdasarkan UndangUndang, dengan tidak mendapat timbal balik secara langsung dan digunakan untuk keperluan negara bagi sebesar-besarnya kemakmuran rakyat. Berdasarkan definisinya, ciri-ciri pajak antara lain: (1) pajak dipungut berdasarkan undangundang, (2) Tidak mendapatkan jasa timbal balik (konraprestasi perseorangan) yang dapat ditunjukkan secara langsung, (3) Pemungutan pajak diperuntukkan bagi keperluan pembiayaan umum pemerintah dalam rangka menjalankan fungsi pemerintahan, baik rutin maupun pembangunan, (4) Pemungutan pajak dapat dipaksakan, (5) Berfungsi mengisi anggaran (budgeter) dan sebagai alat untuk mengatur atau melaksanakan kebijakan negara dalam bidang ekonomi dan sosial (regulasi).

Lembaga pengelola pajak di Indonesia adalah Direktorat Jenderal Pajak (Ditjen Pajak atau DJP) yang bernaung di bawah Departemen Keuangan. Undangundang terbaru yang mengatur sistem perpajakan di Indonesia, antara lain Undang-Undang No 28 Tahun 2007 tentang Perubahan Ketiga atas UndangUndang No. 6 Tahun 1983 tentang Ketentuan Umum dan Tata Cara Perpajakan dan Undang-Undang No. 36 Tahun 2008 tentang Perubahan Keempat atas Undang-Undang No. 7 Tahun 1983 tentang Pajak Penghasilan. Wajib Pajak (WP) adalah Orang Pribadi atau Badan yang menurut ketentuan peraturan perundang-undangan perpajakan ditentukan untuk melakukan kewajiban perpajakan, termasuk pemungut pajak atau pemotong pajak tertentu.

\section{Reformasi Perpajakan}

Pajak bersifat dinamis dan mengikuti perkembangan kehidupan ekonomi dan sosial. Berbagai perbaikan atas sistem perpajakan dilakukan dalam rangka penyesuaian atas perubahan kondisi perekonomian dan sosial di masyarakat. Perubahan mendasar dalam setiap aspek perpajakan dapat disebut sebagai reformasi perpajakan. Menurut 
Pandiangan (dalam Sofyan, 2006), reformasi perpajakan, yang meliputi: (1) formulasi kebijakan dalam bentuk peraturan, dan (2) pelaksanaan dari peraturan, umumnya diarahkan untuk dapat mencapai beberapa sasaran. Salah satu bentuk reformasi perpajakan di Indonesia adalah dengan disahkannya Undang-Undang Nomor 36 Tahun 2008 yang merupakan perubahan keempat dari Undang-Undang Nomor 7 Tahun 1983 tentang Pajak Penghasilan. Undang-Undang Nomor 36 Tahun 2008 ini disahkan pada tanggal 23 September 2008 dan mulai berlaku tanggal 1 Januari 2009.

\section{Penelitian Terdahulu}

Penelitian yang menjadi acuan utama dalam penyusunan usulan penelitian ini adalah penelitian yang dilakukan oleh Richardson (2006) dengan judul "The Impact of Tax Fairness Dimensions on Tax Compliance Behaviour in an Asian Juridiction: The Case of Hong Kong." Tujuan dari penelitian ini adalah untuk menyelidiki dampak dimensi keadilan pajak pada perilaku kepatuhan pajak di Hong Kong yang kemudian akan dibandingkan dengan hasil penelitian yang dilakukan di Amerika Serikat untuk mempertimbangkan setiap kesamaan atau perbedaan perilaku kepatuhan pajak lintasbudaya. Penelitian Richardson (2006) dilakukan dengan survey kuesioner yang dilakukan pada 302 mahasiswa pascasarjana jurusan bisnis di dua universitas di Hong Kong. Hasil penelitiannya menunjukkan bahwa dimensi-dimensi keadilan pajak yang terkait dengan General Fairness, Exchange with Government, dan middle income earners tax share/burden memiliki hubungan positif yang signifikan dengan perilaku kepatuhan pajak di Hong Kong. Namun, dimensidimensi keadilan pajak lainnya, seperti Self Interest, Tax Rate Structure, dan Attittude Towards Taxation of the Wealthy tidak memiliki hubungan yang signifikan. Hasil temuan Richardson (2006) ini tidak konsisten dengan penelitian sebelumnya yang dilakukan di Amerika Serikat.

Penelitian yang dilakukan oleh Azmi dan Perumal (2008) merupakan penelitian yang mereplikasi penelitian Richardson (2006) dengan menggunakan Malaysia sebagai tempat penelitiannya. Berdasarkan hasil analisis faktor, Azmi dan Perumal (2008) menemukan bahwa hanya tiga dimensi keadilan pajak, yaitu General Fairness, Tax Structure, dan Self Interest yang memiliki hubungan positif signifikan terhadap perilaku kepatuhan pajak. Hal ini dikarenakan orang-orang Malaysia menganggap bahwa dimensi Exchange with Government bukanlah bagian yang terpisah dari dimensi 
General Fairness dan dimensi Tax Rate tidak terpisah dari dimensi Special Privileges for the Wealthy. Penelitian ini dilakukan dengan survey kuesioner terhadap 309 pembayar pajak.

Berdasarkan telaah pustaka yang telah dipaparkan, peneliti menggambarkan faktor-faktor yang mempengaruhi perilaku kepatuhan pajak ditinjau dari dimensi keadilan pajak pada Gambar 1.

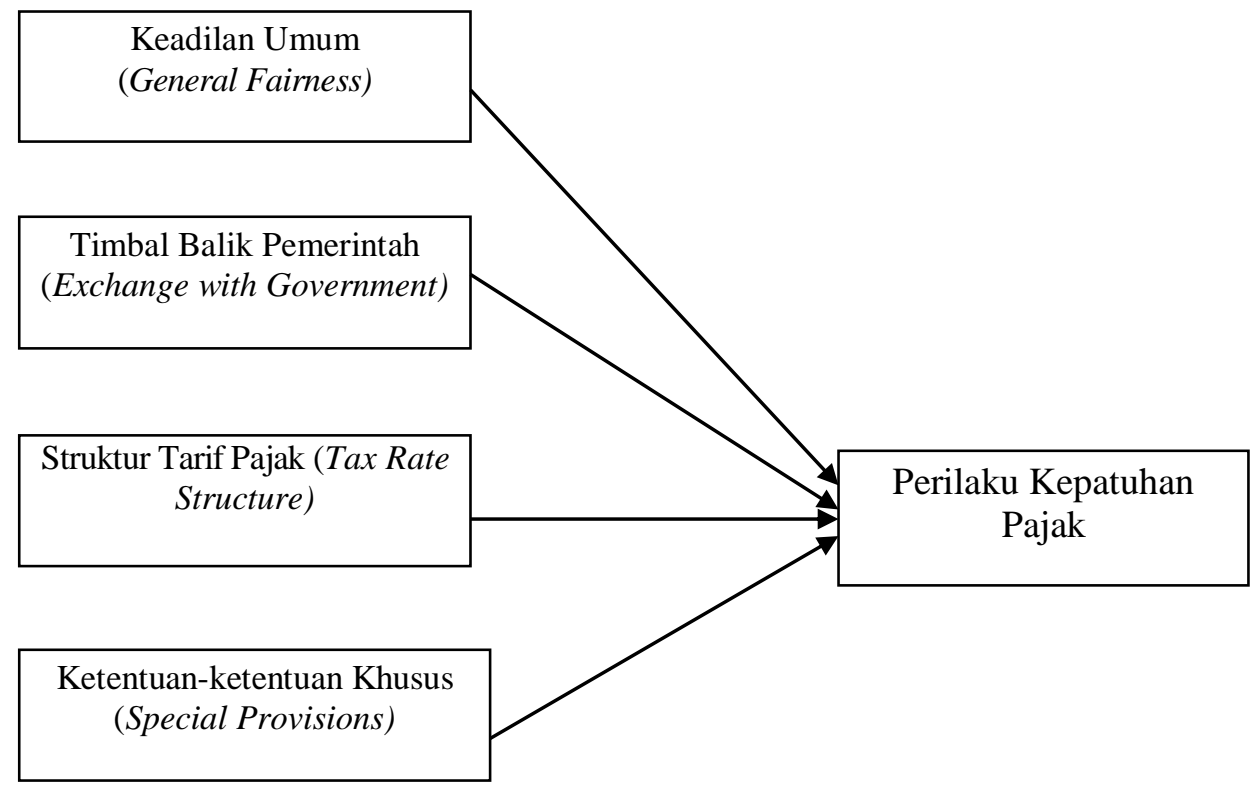

Gambar 1

Kerangka Pemikiran

\section{Pengembangan Hipotesis}

Menurut Jackson dan Milliron (1986), dalam Richardson (2006), dimensi keadilan pajak merupakan variabel nonekonomi kunci yang mempengaruhi perilaku kepatuhan pajak. Namun pengaruh dari dimensi keadilan pajak pada perilaku kepatuhan pajak ini berbeda pada setiap penelitian. Christesen (1994), dalam Azmi dan Perumal (2008), mengungkapkan empat masalah utama yang menyebabkan perbedaan hasil dari penelitian-penelitian sebelumnya, yaitu keadilan pajak (1) merupakan masalah dimensional, (2) dapat didefinisikan pada tingkat individu maupun pada mayarakat luas, (3) keadilan terkait dengan kompleksitas, dan (4) kurangnya keadilan dapat menjadikan pertimbangan atau menyebabkan ketidakpatuhan. Selain keempat masalah tersebut, tidak dapat dihindari adanya pengaruh demografis yang mempengaruhi budaya masyarakat. Hasil penelitian di Hong Kong oleh Richardson (2006) menunjukkan 
beberapa hasil yang berbeda dengan penelitian Gerbing (1988) yang menunjukkan bahwa kependudukan kolonial Inggris tidak mempengaruhi persepsi keadilan pajak masyarakat Hong Kong atau adanya budaya yang berbeda telah mengurangi pengaruh kolonial Inggris.

Azmi dan Perumal (2008) mengidentifikasi lima dimensi keadilan pajak yang mempengaruhi perilaku kepatuhan pajak, yaitu: Keadilan Umum (General Fairness). Dimensi ini terkait dengan keadilan menyeluruh atas sistem perpajakan dan distribusi pajak; Timbal balik Pemerintah (Exchange with Government). Dimensi ini terkait dengan timbal balik yang secara tidak langsung diberikan pemerintah atas pajak yang dibayarkan oleh Wajib Pajak; Kepentingan Pribadi (Self-Interest). Dimensi ini terkait dengan apakah jumlah pajak yang dibayarkan Wajib Pajak secara pribadi terlalu tinggi dan jika dibandingkan dengan Wajib Pajak lainnya; Ketentuan-ketentuan khusus (Special Provisions). Dimensi ini terkait ketentuan-ketentuan khusus yang diberikan kepada Wajib Pajak tertentu, misalnya insentif pengurangan tarif untuk perusahaan go public maupun UMKM. Dimensi ini merupakan penyederhanaan dua dimensi yang telah diidentifikasi oleh Richardson (2006), yaitu Attittude Towards Taxation of the Wealthy dan middle income earners tax share/burden; Struktur Tarif Pajak (Tax Rate Structure). Dimensi ini terkait dengan struktur tarif pajak yang disukai (misalnya struktur tarif pajak progresif vs struktur tarif pajak flat/proporsional).

Berdasarkan pengelompokkan budaya nasional Hofstede, Indonesia diidentifikasikan sebagai negara yang memiliki peringkat dimensi jarak kekuasaan yang tinggi dan peringkat dimensi penghindaran ketidakpastian yang rendah. Kombinasi dari kedua dimensi tersebut menciptakan masyarakat yang berorientasi pada hukum, peraturan, dan pengawasan untuk menghindari ketidakpastian, sementara ketidaksetaraan kekuasaan dan kekayaan tumbuh di masyarakat yang ditunjukkan dengan kecenderungan mengikuti sistem kasta. Oleh karena itu, penelitian ini mempertimbangkan disahkan undang-undang perpajakan yang baru, yaitu UndangUndang No. 36 Tahun 2008 tentang Perubahan Keempat Undang-Undang No. 7 Tahun 1983 tentang Pajak Penghasilan yang mulai berlaku per tanggal 1 Januari 2009. Salah satu perubahan atas undang-undang perpajakan yang dirasa akan sangat mempengaruhi perilaku kepatuhan pajak adalah perubahan struktur tarif pajak menjadi tarif flat bagi 
WP Badan. Berdasarkan landasan teori, kerangka pemikiran, dan uraian di atas, maka hipotesis yang akan diuji dalam penelitian ini adalah sebagai berikut:

H1 : $\quad$ Tingkat keadilan secara umum (general fairness) berpengaruh signifikan terhadap perilaku kepatuhan WP Badan di kota Semarang

H2 : Timbal balik yang diterima pemerintah (exchanges with government) berpengaruh signifikan terhadap perilaku kepatuhan WP Badan di kota Semarang

H3 : Ketentuan-ketentuan yang diberlakukan secara khusus (special provisions) berpengaruh signifikan terhadap perilaku kepatuhan WP Badan di kota Semarang

H4 : $\quad$ Struktur tarif pajak (tax rate structures) sebagai salah satu dimensi keadilan pajak berpengaruh signifikan terhadap perilaku kepatuhan WP Badan di kota Semarang

\section{Metode Penelitian}

\section{Definisi Operasional Variabel}

Variabel independen dari penelitian ini adalah keadilan pajak. Penelitian ini menggunakan lima variabel keadilan pajak yang digunakan dalam penelitian Azmi dan Perumal (2008), yaitu:

1. Keadilan Umum/General Fairness (GENF)

Dimensi keadilan umum terkait dengan keadilan menyeluruh atas sistem perpajakan dan distribusi pajak.

2. Timbal Balik dengan Pemerintah/Exchange with Government (EXCH) Dimensi ini terkait dengan timbal balik yang secara tidak langsung diberikan pemerintah atas pajak yang dibayarkan oleh Wajib Pajak.

3. Ketentuan-ketentuan khusus/Special Provisions (SPEC)

Dimensi ini terkait ketentuan-ketentuan khusus yang diberikan kepada Wajib Pajak tertentu, misalnya insentif pengurangan tarif untuk perusahaan go public maupun UMKM. Dimensi ini merupakan penyederhanaan dua dimensi yang telah diidentifikasi oleh Richardson (2006), yaitu Attittude Towards Taxation of the Wealthy dan middle income earners tax share/burden. 
4. Struktur Tarif Pajak/Tax Rate Structure (TRATE)

Dimensi ini terkait dengan struktur tarif pajak yang disukai (misalnya struktur tarif pajak progresif vs struktur tarif pajak flat/proporsional).

5. Perilaku Kepatuhan Pajak

Variabel dependen dari penelitian ini adalah perilaku kepatuhan pajak (TCOMP). Pengelompokkan perilaku kepatuhan pajak ini menggunakan dua kriteria kepatuhan, yaitu (1) tidak pernah mengalami keterlambatan membayar dan melapor pajak dalam 2 tahun terakhir dan (2) tidak pernah dikenakan sanksi/denda dalam 2 tahun terakhir. Variabel dependen penelitian ini diukur dengan menggunakan skala nominal, yaitu ketika salah satu atau kedua kriteria tersebut tidak terpenuhi, maka Wajib Pajak diasumsikan tidak patuh sehingga diberi nilai 0. Sebaliknya, jika seluruh kriteria tersebut terpenuhi Wajib Pajak dianggap patuh dan diberi nilai 1 .

\section{Jenis dan Sumber Data}

Data yang digunakan dalam penelitian ini merupakan data primer berupa kuesioner yang diisi oleh sampel yang dipilih secara acak. Pengisian kuesioner dilakukan oleh staf akuntansi atau staf perpajakan.yang mewakili Wajib Pajak Badan di kota Semarang. Sedangkan untuk populasi dari penelitian ini adalah Wajib Pajak yang terdaftar di kota Semarang. Wajib Pajak terdaftar ditandai dengan kepemilikan Nomor Pokok Wajib Pajak (NPWP). Wajib Pajak terbagi menjadi dua jenis, yaitu Wajib Pajak Orang Pribadi (WP OP) dan Wajib Pajak Badan (WP Badan). Sampel dalam penelitian ini adalah WP Badan. WP Badan dapat berupa Perseroan Terbatas (PT), Perusahaan Komanditer $(\mathrm{CV})$, yayasan, ataupun organisasi lainnya yang pengelolaan perpajakannya diwakili oleh beberapa orang staf akuntansi dan perpajakan. Pemilihan WP Badan sebagai sampel penelitian ini didasari oleh beberapa alasan sebagai berikut:

1. Kesadaran WP Badan akan pentingnya perpajakan lebih besar dari pada WP OP. Pengelolan pajak internal WP Badan umumnya lebih terorganisir dengan adanya staf akuntansi maupun perpajakan. Di Indonesia, peraturan yang mengatur perusahaan untuk melakukan pemotongan dan pemungutan pajak penghasilan tenaga kerja menjadikan banyak perusahaan atau badan (WP Badan) turut mengelola pajak dari tenaga kerjanya (WP OP). Kondisi tersebut secara tidak 
langsung menjadikan kesadaran WP OP akan perpajakan di kota Semarang kecil.

2. WP Badan lebih memperhatikan berbagai isu mengenai perpajakan, seperti undang-undang, peraturan-peraturan dan tarif pajak, dibandingkan dengan WP OP.

3. WP Badan umumnya diwakili oleh staf akuntansi atau staf perpajakan yang khusus mengelola pajak, sehingga diharapkan memiliki pengetahuan mengenai kondisi perpajakan di kota Semarang cukup atau lebih baik daripada WP OP.

\section{Metode Pengumpulan Data}

Data dikumpulkan dengan menggunakan survei kuesioner terhadap Wajib Pajak Badan. Survei kuesioner yang diberikan merupakan modifikasi dari kuesioner yang digunakan pada penelitian Azmi dan Perumal (2008). Kuesioner terdiri atas 17 pertanyaan yang mewakili 5 dimensi keadilan pajak dengan menggunakan skala likert interval 1 sampai 5. Pada 15 pertanyaan awal, diukur dengan interval 1-sangat tidak setuju sampai 5-sangat setuju. Sedangkan 5 pertanyaan berikutnya, diukur dengan interval 1 -sangat setuju sampai 5-sangat tidak setuju.

\section{Metode Analisis Data}

Hipotesis dalam penelitian ini akan diuji dengan menggunakan analisis regresi logistik (Logistic Regression) karena variabel dependen dalam penelitian ini merupakan variabel dummy dengan persamaan sebagai berikut :

$$
\operatorname{Ln} \frac{\mathrm{P}}{1-\mathrm{P}}=\beta 0+\beta 1 X_{1}+\beta 2 X_{2}+\beta 3 X_{3}+\beta 4 X_{4}+\varepsilon
$$

Dimana:

$\operatorname{Ln} \frac{\mathrm{P}}{1-\mathrm{P}}$ : Perilaku Kepatuhan WP, (1) jika tidak patuh (0) dan jika patuh (1).

$\beta 1, \beta 2, \ldots . \beta 4$ : Koefisien regresi

$\mathrm{X} 1$ : general fairness $\quad \mathrm{X} 2$ : exchanges with government

$\mathrm{X} 3$ : special provisions $\quad \mathrm{X} 4$ : tax rate structures 
Kesimpulan hipotesis yang diambil sebagai berikut :

- H1 diterima jika Sig. $\mathrm{t}<(\alpha)$ pada taraf signifikansi 5\%

- H2 diterima jika Sig. $\mathrm{t}<(\alpha)$ pada taraf signifikansi 5\%

- H3 diterima jika Sig. $\mathrm{t}<(\alpha)$ pada taraf signifikansi 5\%

- H4 diterima jika Sig. $\mathrm{t}<(\alpha)$ pada taraf signifikansi 5\%

\section{Hasil Penelitian dan Pembahasan}

Dalam penentuan sampel penelitian yaitu berdasarkan metode purposive sampling yaitu pengambilan sampel berdasarkan kriteria yang ditetapkan yaitu responden yang masih aktif menjadi Wajib Pajak Badan di Kantor Pelayanan Pajak kota Semarang dan banyaknya responden penelitian 98 dari 150 quesioner yang didistribusikan.

\section{Analisis Data}

Penilaian model fit pada intinya untuk menilai goodness of fit model terhadap data. Untuk menguji hipotesis bahwa data empiris cocok atau tidak dengan model maka digunakan uji Hosmer and Lemeshow's Goodness of Fit Test. Outputnya dapat dilihat pada tabel 4.4 berikut ini :

Tabel 1.

Menilai Goodness Of Fit

Hosmer and Lemeshow Test

\begin{tabular}{|l|r|r|r|}
\hline Step & Chi-square & df & \multicolumn{1}{c|}{ Sig. } \\
\hline 1 & 6.485 & & 8 \\
\hline
\end{tabular}

Hasil uji regresi didapatkan angka signifikansi pada uji Hosmer and Lameshow Test sebesar 0,593 > tingkat signifikansi $(\alpha=5 \%=0,05)$. Hal ini menunjukkan bahwa hipotesis nol diterima dan berarti model ini mampu memprediksi nilai observasinya atau dapat dikatakan bahwa model dapat diterima karena cocok dengan data observasinya. Sedangkan untuk Log Likehood pada regresi mirip dengan pengertian sum of squared error pada model regresi, sehingga penurunan log likehood menunjukkan model regresi yang baik antara variabel bebas yaitu : Keadilan Umum / General Fairness ( $\left.\mathrm{X}_{1}\right)$, Timbal Balik Pemerintah / Exchange with Government $\left(\mathrm{X}_{2}\right)$, Struktur Tarif Pajak / Tax Rate Structure $\left(\mathrm{X}_{3}\right)$ dan Ketentuan-ketentuan Khusus / Special Provisions $\left(\mathrm{X}_{4}\right)$ secara bersama-sama dalam menerangkan variasi variabel terikat (Kepatuhan Wajib Pajak Badan). 
Tabel 2.

Uji Overall Model Fit

\begin{tabular}{|c|c|c|c|c|c|c|c|}
\hline \multirow{2}{*}{\multicolumn{2}{|c|}{ Iteration }} & \multirow{2}{*}{$\begin{array}{l}-2 \log \\
\text { likelihood } \\
\end{array}$} & \multicolumn{5}{|c|}{ Coefficients } \\
\hline & & & Constant & $\mathrm{X} 1$ & $\times 2$ & $\times 3$ & $\times 4$ \\
\hline \multirow{9}{*}{$\begin{array}{ll}\text { Step } \\
1\end{array}$} & 1 & 51.137 & -6.649 & .044 & .143 & .168 & .123 \\
\hline & 2 & 34.819 & -11.239 & .025 & .369 & .277 & .188 \\
\hline & 3 & 28.243 & -16.125 & -.044 & .686 & .400 & .255 \\
\hline & 4 & 25.738 & -21.199 & -.128 & 1.028 & .527 & .327 \\
\hline & 5 & 25.141 & -25.111 & -.177 & 1.270 & .614 & .388 \\
\hline & 6 & 25.089 & -26.698 & -.189 & 1.360 & .644 & .412 \\
\hline & 7 & 25.089 & -26.890 & -.190 & 1.370 & .648 & .415 \\
\hline & 8 & 25.089 & -26.892 & -.190 & 1.370 & .648 & .415 \\
\hline & 9 & 25.089 & -26.892 & -.190 & 1.370 & .648 & .415 \\
\hline \multicolumn{8}{|c|}{ a. Method: Enter } \\
\hline \multicolumn{8}{|c|}{ b. Constant is included in the model. } \\
\hline \multicolumn{8}{|c|}{ c. Initial -2 Log Likelihood: 135.816} \\
\hline \multicolumn{8}{|c|}{$\begin{array}{l}\text { d. Estimation terminated at iteration number } 9 \text { because parameter estimates changed by } \\
\text { less than } .001 \text {. }\end{array}$} \\
\hline
\end{tabular}

Omnibus Tests of Model Coefficients

\begin{tabular}{|ll|r|r|r|}
\hline & & Chi-square & df & \multicolumn{1}{c|}{ Sig. } \\
\hline Step 1 & Step & 110.727 & & .000 \\
& Block & 110.727 & & 4 \\
& Model & 110.727 & & .000 \\
& & 4 & .000 \\
\hline
\end{tabular}

\begin{tabular}{|l|c|c|c|}
\multicolumn{4}{c}{ Model Summary } \\
\hline Step & $\begin{array}{c}-2 \text { Log } \\
\text { likelihood }\end{array}$ & $\begin{array}{c}\text { Cox \& Snell } \\
\text { R Square }\end{array}$ & $\begin{array}{c}\text { Nagelkerke } \\
\text { R Square }\end{array}$ \\
\hline 1 & $25.089^{\mathrm{a}}$ & .677 & .903 \\
\hline
\end{tabular}

a. Estimation terminated at iteration number 9 because parameter estimates changed by less than .001

Dari hasil pengujian diperoleh angka -2 log Likehood (LL) pada awal block number $=0$ sebesar 135,816; sedangkan angka $-2 \log$ Likehood (LL) pada block number = 1 sebesar 110,727. Hal ini menunjukkan penurunan angka -2 log Likehood sebesar (block number 0 - block number 1$)=(135,816-110,727)=25,089$ sehingga penelitian ini tergolong model regresi yang baik. Sedangkan pengujian secara keseluruhan (serentak) dengan menggunakan Omnibus Test diperoleh nilai chi square sebesar 110,727 dan dengan signifikansi 0,000. Dengan nilai signifikansi sebesar 0,000 tersebut menunjukkan nilai yang lebih kecil dari 0,05. Hal ini berarti secara bersama-sama keempat variabel bebas berpengaruh signifikan terhadap Kepatuhan Wajib Pajak. Dari hasil uji overall model fit pada pengujian Cox and Snell $R$ Square sebesar 0,677 dan Negelkerke $R$ Square adalah 0,903 yang berarti variabilitas variabel dependen yang dapat dijelaskan oleh variabilitas variabel independen sebesar 90,30\%. 


\section{Uji Hipotesis}

Untuk menguji hipotesis digunakan regresi logistik. Hasilnya tampak pada tabel 4.6 berikut :

Tabel 3.

Hasil Regresi Logistik

Variables in the Equation

\begin{tabular}{|c|c|c|c|c|c|c|c|c|c|}
\hline & \multirow[b]{2}{*}{ B } & \multirow[b]{2}{*}{ S.E. } & \multirow[b]{2}{*}{ Wald } & \multirow[b]{2}{*}{ df } & \multirow[b]{2}{*}{ Sig. } & \multirow[b]{2}{*}{$\operatorname{Exp}(B)$} & \multicolumn{2}{|c|}{$95.0 \%$ C.l.for $\operatorname{EXP}(B)$} \\
\hline & & & & & & & & Lower & Upper \\
\hline \multirow{5}{*}{$\begin{array}{l}\text { Step } \\
1\end{array}$} & $\mathrm{X} 1$ & -.190 & .244 & .603 & $\overline{1}$ & .437 & .827 & .512 & 1.335 \\
\hline & $\times 2$ & 1.370 & .541 & 6.416 & 1 & .011 & 3.937 & 1.363 & 11.366 \\
\hline & X3 & .648 & .254 & 6.481 & 1 & .011 & 1.911 & 1.161 & 3.147 \\
\hline & $\mathrm{X} 4$ & .415 & .202 & 4.240 & 1 & .039 & 1.515 & 1.020 & 2.250 \\
\hline & Constant & -26.892 & 8.098 & 11.027 & 1 & .001 & .000 & & \\
\hline
\end{tabular}

a. Variable(s) entered on step 1: X1, X2, X3, X4.

Sumber : Data sekunder yang diolah, tahun 2013

Berdasarkan tabel di atas, maka model persamaan regresi logistik dapat dijabarkan yaitu

$$
\operatorname{Ln} \frac{P}{1-P}=-26,892-0,190 X_{1}+1,370 X_{2}+0,648 X_{3}+0,415 X_{4}
$$

Dari persamaan regresi logistik di atas dapat dijelaskan sebagai berikut :

a. Konstanta sebesar -26,892 mengindikasikan bahwa jika semua variabel bebas penelitian dianggap konstan, maka akan semakin rendah/kepatuhan Wajib Pajak Badan sebesar 36,892.

b. Koefisien regresi variabel Keadilan Umum / General Fairness sebesar -0,190 mengindikasikan bahwa artinya bila semakin tinggi Keadilan Umum / General Fairness sebesar 1\% sedangkan faktor lain dianggap konstan, maka cenderung menurunkan kepatuhan wajib pajak. Nilai probabilitas (p) pada variabel Keadilan Umum / General Fairness terhadap Kepatuhan Wajib Pajak Badan sebesar 0,437 lebih besar dibandingkan tingkat signifikansi $(\alpha=5 \%=0,05)$ dan nilai koefisien regresi sebesar -0,190 yang berarti bahwa variabel Keadilan Umum / General Fairness tidak berpengaruh signifikan terhadap Kepatuhan Wajib Pajak Badan. Tidak adanya pengaruh yang signifikan ini menjelaskan bahwa tinggi rendahnya tingkat Keadilan Umum / General Fairness tidak mempengaruhi Wajib Pajak dalam melakukan pembayaran pajak badan. Hal ini dapat disebabkan karena wajib 
pajak badan dalam pengisian SPT belum memiliki kesadaran yang tinggi dalam pembayaran pajak badan.

c. Koefisien regresi variabel Timbal Balik Pemerintah / Exchange with Government sebesar 1,370 mengindikasikan bahwa artinya bila semakin baik Timbal Balik Pemerintah sebesar 1\% sedangkan faktor lain dianggap konstan, maka cenderung meningkatkan Kepatuhan Wajib Pajak Badan. Nilai probabilitas (p) pada variabel Timbal Balik Pemerintah terhadap Kepatuhan Wajib Pajak Badan sebesar 0,011 lebih kecil dibandingkan tingkat signifikansi $(\alpha=5 \%=0,05)$ dan nilai koefisien regresi sebesar 1,370 yang berarti bahwa variabel Timbal Balik Pemerintah berpengaruh signifikan dan positif terhadap Kepatuhan Wajib Pajak Badan. Adanya pengaruh yang signifikan dan positif ini menjelaskan bahwa semakin baik Timbal Balik Pemerintah mempengaruhi Wajib Pajak Badan dalam memenuhi kepatuhan Wajib Pajak.

d. Koefisien regresi variabel situasi Struktur Tarif Pajak / Tax Rate Structure sebesar 0,648 mengindikasikan bahwa artinya bila semakin baik Struktur Tarif Pajak sebesar $1 \%$ sedangkan faktor lain dianggap konstan, maka cenderung Kepatuhan Wajib Pajak Badan. Nilai probabilitas (p) pada variabel Struktur Tarif Pajak terhadap Kepatuhan Wajib Pajak Badan sebesar 0,011 lebih kecil dibandingkan tingkat signifikansi $(\alpha=5 \%=0,05)$ dan nilai koefisien regresi sebesar 0,648 yang berarti bahwa variabel Struktur Tarif Pajak berpengaruh signifikan dan positif terhadap Kepatuhan Wajib Pajak Badan. Adanya pengaruh yang signifikan ini menjelaskan bahwa semakin tinggi Struktur Tarif Pajak mempengaruhi Kepatuhan Wajib Pajak Badan.

e. Koefisien regresi variabel Ketentuan-ketentuan Khusus / Special Provisions sebesar 0,415 mengindikasikan bahwa artinya bila semakin baik Ketentuanketentuan Khusus sebesar 1\% sedangkan faktor lain dianggap konstan, maka akan meningkatkan Kepatuhan Wajib Pajak Badan. Nilai probabilitas (p) pada variabel Ketentuan-ketentuan Khusus terhadap Kepatuhan Wajib Pajak Badan sebesar 0,039 lebih kecil dibandingkan tingkat signifikansi $(\alpha=5 \%=0,05)$ dan nilai koefisien regresi sebesar 0,415 yang berarti bahwa variabel Ketentuan-ketentuan Khusus berpengaruh signifikan dan positif terhadap Kepatuhan Wajib Pajak Badan. Adanya pengaruh yang signifikan dan positif ini menjelaskan bahwa 
semakin baik Ketentuan-ketentuan Khusus mempengaruhi Kepatuhan Wajib Pajak Badan dalam pembayaran pajak.

\section{Pembahasan}

\section{Pengaruh Keadilan Secara Umum terhadap Kepatuhan Wajib Pajak Badan}

Hasil pengujian menunjukkan bahwa variabel keadilan secara umum secara statistik tidak berpengaruh signifikan terhadap kepatuhan wajib pajak badan. Peningkatan dimensi keadilan umum dapat meningkatkan perilaku kepatuhan pajak namun tidak dapat menjadi tolok ukur yang signifikan. Wajib Pajak Badan menganggap bahwa sistem perpajakan dan pendistribusian pajak secara umum telah adil, namun rasa keadilan ini tidak mempengaruhi perilaku kepatuhan pajaknya. Wajib Pajak Badan lebih berorientasi pada aturan yang berlaku dan sanksi yang mungkin diterima dalam membayar pajak dibandingkan keadilan yang mereka terima. Hasil pengujian ini berbeda dengan penelitian yang dilakukan oleh Richardson (2006) serta Azmi dan Perumal (2008) yang menyatakan bahwa dimensi keadilan umum berpengaruh signifikan pada perilaku kepatuhan pajak di Hong Kong dan Malaysia.

\section{Pengaruh Timbal Balik Pemerintah (Exchange with Govermance) terhadap Kepatuhan Wajib Pajak Badan}

Hasil pengujian menunjukkan bahwa dimensi timbal balik pemerintah secara statistik berpengaruh signifikan terhadap kepatuhan wajib pajak badan. Timbal balik yang diberikan pemerintah sebagai kompensasi pembayaran pajak merupakan timbal balik yang diberikan secara langsung sehingga Wajib Pajak Badan dapat merasakan manfaatnya secara menyeluruh. Nilai manfaat atas timbal balik pemerintah atas pembayaran pajak ini tidak menjadi alasan Wajib Pajak Badan untuk patuh dalam membayar pajak. Dengan kata lain, perilaku kepatuhan pajak dipengaruhi oleh perasaan adil Wajib Pajak Badan atas timbal balik yang diberikan pemerintah. Wajib Pajak Badan akan tetap membayar pajak penghasilannya meskipun mereka merasa adil atau pun tidak dengan timbal balik yang diberikan pemerintah. Hasil pengujian ini tidak sesuai dengan penelitian Azmi dan Perumal (2008) di Malaysia bahwa variabel timbal balik pemerintah tidak berpengaruh signifikan pada perilaku kepatuhan pajak. 


\section{Pengaruh Struktur Tarif Pajak (Tax Rate Structure) terhadap Kepatuhan Wajib}

\section{Pajak Badan}

Hasil pengujian menunjukkan bahwa struktur tarif pajak secara statistik berpengaruh signifikan terhadap kepatuhan wajib pajak badan. Perubahan struktur tarif pajak yang berlaku dari tarif proporsional menjadi tarif flat dapat menjadi alasan Wajib Pajak Badan untuk patuh atau tidak dalam membayar pajak. Baik tarif pajak dikenakan secara proporsional maupun flat, Wajib Pajak Badan akan tetap membayarkan pajaknya. Wajib Pajak yang patuh akan mempertimbangkan struktur tarif pajak dalam membayarkan pajak. Hasil pengujian ini sesuai dengan penelitian yang dilakukan oleh Azmi dan Perumal (2008) yang menyatakan bahwa struktur tarif pajak berpengaruh signifikan terhadap perilaku kepatuhan pajak di Malaysia.

\section{Pengaruh Ketentuan-ketentuan Khusus (Special Provisions) terhadap} Kepatuhan Wajib Pajak Badan

Hasil pengujian menunjukkan bahwa ketentuan-ketentuan khusus secara statistik berpengaruh signifikan terhadap perilaku kepatuhan pajak. Adanya ketentuan-ketentuan khusus yang meringankan Wajib Pajak Badan dalam membayarkan pajak mempengaruhi perilaku kepatuhannya dalam membayar pajak. Ketentuanketentuan khusus yang dapat meningkatkan pajak yang dibayarkan dirasakan adil oleh Wajib Pajak Badan karena telah memberikan keringanan pada seluruh lapisan penghasilan, baik yang berpenghasilan kecil (misalnya UMKM) maupun perusahaan besar (misalnya perusahaan go public). Keputusan Wajib Pajak Badan untuk membayarkan pajaknya secara tepat waktu bukan karena perasaan adil karena adanya keringanan-keringanan tertentu tetapi lebih pada rasa keterikatan mereka pada peraturan yang berlaku. Hasil pengujian ini tidak sesuai dengan penelitian yang dilakukan oleh Azmi dan Perumal (2008) yang menyatakan bahwa ketentuan-ketentuan khusus tidak berpengaruh signifikan terhadap perilaku kepatuhan pajak di Hong Kong dan Malaysia. 


\section{Simpulan dan Saran}

\section{Simpulan}

Dari hasil penelitian dan pembahasan pada bab sebelumnya, maka dapat diambil beberapa kesimpulan sebagai berikut :

1. Keadilan Umum / General Fairness tidak berpengaruh signifikan terhadap Kepatuhan Wajib Pajak Badan. Tidak adanya pengaruh yang signifikan ini menjelaskan bahwa tinggi rendahnya tingkat Keadilan Umum / General Fairness tidak mempengaruhi Wajib Pajak dalam melakukan pembayaran pajak badan. Hal ini dapat disebabkan karena wajib pajak badan dalam pengisian SPT belum memiliki kesadaran yang tinggi dalam pembayaran pajak badan.

2. Timbal Balik Pemerintah berpengaruh signifikan dan positif terhadap Kepatuhan Wajib Pajak Badan. Adanya pengaruh yang signifikan dan positif ini menjelaskan bahwa semakin baik Timbal Balik Pemerintah mempengaruhi Wajib Pajak Badan dalam memenuhi kepatuhan Wajib Pajak.

3. Struktur Tarif Pajak berpengaruh signifikan dan positif terhadap Kepatuhan Wajib Pajak Badan. Adanya pengaruh yang signifikan ini menjelaskan bahwa semakin tinggi Struktur Tarif Pajak mempengaruhi Kepatuhan Wajib Pajak Badan.

4. Ketentuan-ketentuan Khusus berpengaruh signifikan dan positif terhadap Kepatuhan Wajib Pajak Badan. Adanya pengaruh yang signifikan dan positif ini menjelaskan bahwa semakin baik Ketentuan-ketentuan Khusus mempengaruhi Kepatuhan Wajib Pajak Badan dalam pembayaran pajak.

\section{Saran-saran}

Adapun saran-saran yang dapat diajukan di dalam penelitian ini adalah sebagai berikut :

1. Walau tidak berpengaruh signifikan, azas keadilan umum harus tetap ditegakkan, sehingga setiap wajib pajak harus membayar pajak sesuai dengan kewajibannya.

2. Pemerintah harus memberikan transparansi dari timbal balik pemerintah sehingga wajib pajak semakin tertarik untuk patuh dalam membayar pajak.

3. Struktur pajak yang ada harus dikembangkan agar memudahkan wajib pajak dalam pembayaran pajak untuk mendorong keinginan pembayaran pajak.

4. Pemerintah harus memberikan peraturan-peraturan khusus untuk wajib pajak tertentu agar mendorong pembayaran pajak dari wajib pajak. 


\section{Keterbatasan}

Penelitian ini mempunyai keterbatasan yaitu :

1. Sampel penelitian adalah Wajib Pajak Badan yang ada di wilayah Kantor Pelayanan Pajak Kota Semarang. Wajib Pajak Badan yang menjadi responden dalam penelitian ini tidak diklasifikasikan menurut jenis-jenis usahanya sehingga pengidentifikasian responden kurang spesifik..

2. Variabel bebas yang diteliti dibatasi pada Keadilan Secara Umum, Timbal Balik Pemerintah, Struktur Tarif Pajak dan Ketentuan-ketentuan Khusus. Sedangkan variabel terikatnya adalah kepatuhan Wajib Pajak.

\section{Agenda Penelitian yang Akan Datang}

1. Mengidentifikasikan responden Wajib Pajak Badan ke dalam pengklasifikasian menurut jenis-jenis usahanya.

2. Menambahkan variabel lain yang mungkin memiliki pengaruh pada kepatuhan wajib pajak badan antara lain: pelayanan petugas pajak, transparansi penggunaan pajak.

\section{DAFTAR PUSTAKA}

Azmi, Anna A. Che and Kamala A. Perumal. 2008. "Tax Fairness Dimensions in an Asian Context: The Malaysian Perspective", International Review of Business Research Papers, Vol. 4 No.5 October-November 2008 Pp.11-19.

Darmayanti, Theresia Woro, 2004. Pelaksanaan Self Assesment System Menurut Wajib Pajak (Studi Kasus pada Wajib Pajak Badan Salatiga). Jurnal Ekonomi dan Bisnis. Volume X No. 1, $109-128$.

Ghozali, Imam. 2005. Aplikasi Analisis Multivariate dengan Program SPSS. Semarang: Badan Penerbit Universtas Diponegoro

Hofstede, Geert. 1980. "Dimensions of National Cultures”, http://geerthofstede.com/,

Mustikasari, Elia. 2007. "Kajian Empiris tentang Kepatuhan Wajib Pajak Badan di Perusahaan Industri Pengolahan di Surabaya.” Simposium Nasional Akuntansi X Makassar, ASPP 16.

Richardson, Grant. 2006. "The Impact of Tax Fairness Dimensions on Tax Compliance Behavior in an Asian Jurisdiction: The Case of Hong Kong", International Tax Journal

Singarimbun, Masri dan Sofian Efendi, 1997. Metode Penelitian Survey, PT. Pustaka LP3ES, Jakarta. 
Sofyan, Marcus Taufan. 2006. "Pengaruh Penerapan Sistem Administrasi Perpajakan Modern terhadap Kepatuhan Wajib Pajak pada Kantor Pelayanan Pajak di Lingkungan Kantor Wilayah Direktorat Jenderal Pajak Wajib Pajak Besar". Skripsi. Tangerang.

Wardhani, Rulyanti Susi. 2005. "Pengaruh Pemahaman Akuntansi Pajak terhadap Kepatuhan Wajib Pajak Badan dalam Memenuhi Kewajiban Pajak Penghasilan di KPP Palembang Ilir Timur”. Jurnal Fordema Vol. 5 No. 1 Juni 2005. 